Научная статья

УДК 373.2

DOI: $10.18101 / 2307-3330-2021-4-28-32$

\title{
ТЕОРЕТИЧЕСКИЙ АНАЛИЗ ПСИХОЛОГО-ПЕДАГОГИЧЕСКИХ УСЛОВИЙ ДЛЯ РАЗВИТИЯ КООРДИНАЦИИ ДВИЖЕНИЙ У ДЕТЕЙ ДОШКОЛЬНОГО ВОЗРАСТА В ТАНЦЕВАЛЬНОЙ ДЕЯТЕЛЬНОСТИ
}

\author{
(C) Березовская Ирина Николаевна \\ студентка, \\ Иркутский государственный университет \\ Россия, 664003 г. Иркутск, ул. Карла Маркса, 1 \\ Iren433@mail.ru \\ (C) Шинкарева Надежда Алексеевна \\ кандидат педагогических наук, доцент, \\ Иркутский государственный университет \\ Россия, 664003 г. Иркутск, ул. Карла Маркса, 1 \\ Iren433@mail.ru
}

\begin{abstract}
Аннотация. В данной статье рассматриваются особенности организации психолого-педагогических условий развития координации движений у детей старшего дошкольного возраста в танцевальной деятельности, представлены взгляды различных авторов и разобраны условия успешности организации работы по трем направлениям: педагоги, среда, родители.

Конкретизированы такие условия, как повышение осведомленности и интереса родителей по вопросу развития координации движений у детей дошкольного возраста; повышение компетентности педагогов по организации работы по развитию координации движений у детей дошкольного возраста в танцевальной деятельности; пополнение развивающей предметно-пространственной среды, способствующей развитию координации движений у старших дошкольников в танцевальной деятельности. В статье перечислены конкретные виды музыкально - ритмических движений, эффективные направления работы с родителями и методы.

Ключевые слова: дошкольное образование, психолого-педагогические условия, дети старшего дошкольного возраста, «образовательная среда», работа с родителями, «профессиональная компетентность педагога».
\end{abstract}

\section{Для цитирования}

Березовская И. Н., Шинкарева Н. А. Теоретический анализ психолого-педагогических условий для развития координации движений у детей дошкольного возраста в танцевальной деятельности // Вестник Бурятского государственного университета. Образование. Личность. Общество. 2021. № 4. С. 28-32. 
И. Н. Березовская, Н. А. Шинкарева. Теоретический анализ психолого-педагогических условий для развития координации движений у детей дошкольного возраста в танцевальной деятельности

На сегодня дошкольное образование выступает как целостная система, центральное место в которой отведено как содержанию и формам работы, так и непосредственному процессу взаимодействия всех участников образовательных отношений.

Е. Ф. Бехтенова, рассматривая вопрос организации педагогических условий, говорит, что это такие условия, которые определяют «качественную характеристику основных факторов, процессов и явлений образовательной среды» [2, с. 23].

А. К. Маркова, рассуждая об успешности организации работы по формированию координации движений у дошкольников, сформулировала следующие условия:

1) повышение осведомленности и интереса родителей по вопросу развития координации движений у детей дошкольного возраста;

2) повышение компетентности педагогов по организации работы по развитию координации движений у детей дошкольного возраста в танцевальной деятельности;

3) пополнение развивающей предметно-пространственной среды, способствующей развитию координации движений у старших дошкольников в танцевальной деятельности [6, с. 178].

Рассматривая каждое условие более подробное, в первую очередь обратимся к вопросу повышения осведомленности и интереса родителей по развитию координации движений у дошкольников.

М. М. Багманян выделяет четыре ключевые направления при работе с родителями:

1) информационно-аналитические (общения с родителями являются сбор, обработка и использование данных о семье);

2) познавательные (обогащение родителей знаниями по формирования основ физической культуры детей дошкольного возраста);

3) наглядно-информационные (ознакомление родителей с условиями, содержанием и методами воспитания детей в условиях ДОО);

4) досуговые (неформальные отношения между педагогами и родителями, родителями и детьми) [1, с. 21].

Вторым, но не менее значимым, является вопрос повышения компетентности педагогов в ходе осуществления работы по развитию координации движений у детей дошкольников в танцевальной деятельности.

С. Е. Шишов трактует понятие «профессиональная компетентность педагога» как общую способность мобилизовать свои знания и умения и быть способным использовать их в реальной практической работе [7, с. 50].

В процессе проведения работы по развитию координации движений на танцевальных занятиях важнейшим условием выступает постепенность в усложнении задач, наличие большого разнообразия движений и ускоренного темпа.

Г. А. Колодницкий выстроил определенную последовательность при проведении общеразвивающих упражнений по ориентировке в пространстве:

1) движения рук в поле зрения ребенка (разные варианты упражнений с вытягиванием рук вперед, помахиванием перед собой и пр.); 
2) движения рук, находящихся частично в поле зрения (поднимание вверх, в стороны, назад - со сгибанием, вращением в суставах - в каком-либо одном направлении);

3) движения туловища в лицевой, боковой и затем горизонтальной плоскости;

4) движения ног вперед, в стороны, назад;

5) движения разных частей тела по направлению к каким-либо конкретным предметам, затем по слову в названном направлении;

6) движения разных частей тела по направлению к другому ребенку [5, c. 63].

Упражнения на ориентировку во времени следует преподавать в следующем порядке:

1) упражнения, подкрепленные словесным описанием педагога. При этом указания, команды и паузы выдерживаются в определенном ритме, с использованием акцентирования;

2) упражнения в сопровождении музыки [5, с. 65].

C. С. Иванова в своих трудах говорит, что на танцевальном занятии по развитию координации движений педагогом используются следующие методы:

1) стандартно-повторного упражнения. Освоение новых за счет повторения уже знакомых действий;

2) вариативного упражнения. Наличие все возможной вариативности и интерпретации проводимых упражнений;

3) игровой. Изменение условий проведения упражнений: продолжительность, место, двигательные действия;

4) соревновательный. Специально подобранные комплексы упражнений с дополнительной соревновательной-мотивацией $[4$, с. 38$]$.

Согласно М. Б. Зацепиной, обращаясь к ее программе «Музыкальное образование в детском саду», существуют конкретные виды музыкально-ритмических движений:

1. Игры (сюжетные, несюжетные).

2. Пляски (импровизации, с фиксированными движениями).

3. Упражнения (совершенствующие основные движения, образные, подготовительные упражнения, композиция) [3, с. 38].

Третьим условием выступает наполнение развивающей предметно-пространственной среды, способствующей развитию координации движений у старших дошкольников в танцевальной деятельности.

На занятиях танцевальной деятельности музыкальное сопровождение становится делом первостепенной важности, с помощью него ребенок учится не просто определять характер музыки, но и подстраивать на его основе свои движения. К предметно-пространственной среде также можно также отнести музыкальнотанцевальный зал, оборудованный необходимым для педагогического процесса материалом (музыкальные инструменты, магнитофон, микрофон). Наполнение среды в музыкально-танцевальном зале подразумевает наличие музыкальных игрушек (балалайка, гармошка, клавиатура пианино, неваляшка, музыкальный волчок), игрушек-самоделок: (шумовые коробочки, палочки для отстукивания ритма, 
И. Н. Березовская, Н. А. Шинкарева. Теоретический анализ психолого-педагогических условий для развития координации движений у детей дошкольного возраста в танцевальной деятельности

кубики для отстукивания ритма, шумелки из пробок), костюмов, используемых для постановок и музыкальных игр.

Таким образом, изучив психолого-педагогическую литературу по данной проблеме, в своей исследовательской работе мы будем использовать взгляды авторов, а именно: повышение осведомленности и интереса родителей по вопросу развития координации движений у детей дошкольного возраста; повышение компетентности педагогов в области организации работы по развитию координации движений у детей дошкольного возраста в танцевальной деятельности; пополнение развивающей предметно-пространственной среды, способствующей развитию координации движений у старших дошкольников в танцевальной деятельности; игры (сюжетные, несюжетные); пляски (импровизации, с фиксированными движениями); упражнения (совершенствующие основные движения, образные, подготовительные упражнения, композиция).

\section{Литература}

1. Багманян М. М. Взаимодействие ДОО и семьи по формированию представлений о ЗОЖ у детей старшего дошкольного возраста // Научно-методический электронный журнал «Концепт». 2016. № 10. С. 21-25. Текст: непосредственный.

2. Бехтенова Е. Ф. Педагогические условия формирования проектной деятельности учащихся. Новосибирск, 2006. 23 с. Текст: непосредственный.

3. Зацепина М. Б. Музыкальное воспитание в детском саду. Москва: Мозаика-Синтез, 2006. 96 с. Текст: непосредственный.

4. Иванова С. С. Формирование координационных способностей детей дошкольного возраста средствами оздоровительной работы в дошкольном образовательном учреждении // Асгард. 2015. № 7. С. 38-41. Текст: непосредственный.

5. Колодницкий Г. А., Колодницкий Г. А., Кузнецов В. С. Физическая культура. Ритмические упражнения, хореография и игры: методическое пособие. Москва: Дрофа, 2003. 96 с. Текст: непосредственный.

6. Маркова А. К. Психология профессионализма. Москва: Знание, 1996. 308 с. Текст: непосредственный.

7. Шишов С. Е., Кальней В. А. Мониторинг качества образования в школе. Москва: Педагогическое общество России, 1999. 354 с. Текст: непосредственный.

Статья поступила в редакцию 02.10.2021; одобрена после рецензирования 13.10.2021; принята к публикачии 15.12.2021.

\section{THE THEORETICAL ANALYSIS OF PSYCHOLOGICAL AND PEDAGOGICAL CONDITIONS FOR THE DEVELOPMENT OF MOVEMENTS COORDINATION IN PRESCHOOL CHILDREN'S DANCE ACTIVITITY}

Irina N. Berezovskaya

student

Irkutsk State University

1 Karl Marx St., Irkutsk, 664003, Russia

Iren433@mail.ru 
Nadezhda A. Shinkareva

candidate of Pedagogical Sciences, Associate Professor

Irkutsk State University

1 Karl Marx St., Irkutsk, 664003, Russia

Iren433@mail.ru

This article examines the features of the organization of psychological and pedagogical conditions for the development of movements coordination in senior preschool children's dance activities; presents the views of various authors and analyzes the conditions for the successful organization of work in three areas: teachers, environment, parents.

The authors specified conditions such as raising awareness and interest of parents to the development of movements coordination of preschool children, increasing the competence of teachers in organizing work to develop movements coordination in preschool children's dance activities; replenishment of the developing subject-spatial environment, stimulating the development of movements coordination in senior preschoolers' dance activities.

The article lists specific types of musical and rhythmic movements, effective areas of work with parents and methods.

Keywords: preschool education, psychological and pedagogical conditions, children of senior preschool age, «educational environment», work with parents, «professional competence of a teacher».

The article was submitted 02.10.2021; approved after reviewing 13.10.2021; accepted for publication 15.12.2021. 